\title{
The Empirical Measurement of Interest Rate Risk of China's Commercial Banks in the Process of Interest Rate Liberalization
}

\author{
Binjia Yang ${ }^{1} \&$ Gendi Wen $^{1}$ \\ ${ }^{1}$ China Minsheng Banking Corporation, Beijing, China \\ Correspondence: Gendi Wen, China Minsheng Banking Corporation, Beijing 100031, China. E-mail: \\ wengendi@gmail.com \\ Received: May 26, 2014 \\ Accepted: June 8, 2014 \\ Online Published: June 19, 2014 \\ doi:10.5430/ijfr.v5n3p188 \\ URL: http://dx.doi.org/10.5430/ijfr.v5n3p188
}

\begin{abstract}
With China's financial system reform deepening, interest rate liberalization reform has sharply entered an accelerating course. This paper focuses on the interest rate risk of China's commercial banks in the process of interest rate liberalization. Based on the literature review on interest rate risk management of commercial banks, this paper carries out an empirical analysis on four forms of interest rate risk under the certain background of China, repricing risk, basis risk, optional risk and yield curve risk. Based on the Interest Rate Sensitive Gap Approach and Duration Model, this paper carries out an empirical measurement of interest rate risk of China's commercial banks in the process of interest rate liberalization. In the end, this paper proposes the countermeasures and suggestions for the interest rate risk management practice of China's commercial banks.
\end{abstract}

Keywords: interest rate liberalization, interest rate risk, interest rate risk management

\section{Introduction}

Interest rate liberalization exerts a profound influence on the risk structure of commercial banks. Because of the frequent and drastic fluctuation of interest rate, interest rate risk has become a major risk just second to credit risk. Thus, how to enhance the management of interest rate risk and establish an effectively preventive institution to avoid or compensate interest rate risk has become an absolutely important issue for China's commercial banks in the process of interest rate liberalization.

\section{Literature Review}

Li Yan (2002) used interest rate sensitive ratio and deviation rate to make an empirical study on the interest rate risk of China's commercial banks based on the data between 1996 and 1999, and pointed out that China's commercial banks faced the tremendous interest rate risk during this certain period. Huang Jinlao (2001) stated that China's commercial banks face not only the permanent risk but also the periodical risk in the certain period of interest rate liberalization which is promoted gradually. Chen Bo \& Yao Jianli (2005) suggested to apply two-stage strategy and duration technology into the interest rate risk management. The first stage is to establish an interest rate risk management system which relies on sensitive gap while takes duration gap as a secondary reliance, the second stage is to establish the system which relies on duration gap which takes the trade of financial derivatives as a secondary reliance. Wang Heying (2008) contended that China's financial derivative market was in a primary stage, the simple product structure and imperfect function made it difficult for commercial banks to spread or transfer interest rate risk. Wang Qiang (2010) analyzed four forms of interest rate risk and put forward the corresponding countermeasures and suggestions. Deng Ran (2011) raised some suggestions for China's commercial banks about how to prevent interest rate risk based on the analysis of the tendency of interest rate risk in 2010. Yao Yuan (2012) carried out an empirical research based on the date from 7 listed banks from 2007 to 2011, and pointed out that the more-than-one-year asset of China's commercial banks could not match the corresponding liability, the adjusting speed of interest rate sensitive gap was slower than the change of interest rate, which resulted in the long-term interest rate risk for commercial banks.

\section{The Empirical Analysis of Interest Rate Risk Display Forms of China's Commercial Banks}

\subsection{Repricing Risk}

The repricing risk of China's commercial banks is mainly from two aspects: 
The first aspect is term mismatch, which shows that the deposits of China's commercial banks are often short term but the loans are often long term. See Table 1. The balance sheets of China's commercial banks reveal that the terms of assets and liabilities mismatch, which also means the scale of interest rate sensitive liabilities is bigger than the interest rate sensitive assets. As a result, the interest rate sensitive gab appears in China's commercial banks. Take CMBC(China Minsheng Banking Corporation) for example. As Table 2 shows, the scale of deposits which term is shorter than or equal to three months is 5,805.47(100million Yuan) larger than the scale of corresponding loans in 2013 year, while the scale of loans which term is between three months and one year is 1,629.94 (100million Yuan) larger than the scale of corresponding deposits. This kind of phenomenon that the term of deposits is short while the term of loans is long is also very common in other commercial banks in China.

Table 1. The structure of deposits and loans of financial institutions in China between 2011 and 2013

Unit: 100million Yuan

\begin{tabular}{cccc}
\hline Item & 2011 year & 2012 year & 2013 year \\
\hline Total deposits & $733,382.03$ & $826,701.35$ & $943,102.27$ \\
\hline Current deposits & $392,506.06$ & $449,477.53$ & $510,972.81$ \\
\hline Fixed deposits & $340,875.97$ & $377,223.82$ & $432,129.46$ \\
\hline $\begin{array}{c}\text { The proportion of } \\
\text { current deposits(\%) }\end{array}$ & 53.52 & 54.37 & 54.18 \\
\hline Total loans & $509,225.95$ & $581,892.50$ & $672,874.61$ \\
\hline Short-term loans & $248,502.26$ & $277,679.10$ & $324,863.86$ \\
\hline $\begin{array}{c}\text { Medium and } \\
\text { long-term loans }\end{array}$ & $260,723.69$ & $304,213.40$ & $348,010.75$ \\
\hline $\begin{array}{c}\text { The proportion of } \\
\text { Medium and } \\
\text { long-term loans(\%) }\end{array}$ & 51.20 & 52.28 & 51.72 \\
\hline
\end{tabular}

Data source: The People's Bank of China (www.pbc.gov.cn)

Table 2. The term structure of deposits and loans of CMBC in 2013 year

Unit: 100million Yuan

\begin{tabular}{cccccc}
\hline & Total & $\begin{array}{c}\text { Shorter than or equal } \\
\text { to 3 months }\end{array}$ & 3 months to 1 year & 1 to 5 years & $\begin{array}{c}\text { Longer than 5 } \\
\text { years }\end{array}$ \\
\hline Loans & $12,052.21$ & $7,291.86$ & $4,433.47$ & 276.41 & 50.47 \\
\hline Deposits & $16,447.38$ & $13,097.33$ & $2,803.53$ & 535.63 & 10.89 \\
\hline Gap & $-4,395.17$ & $-5,805.47$ & $1,629.94$ & -259.22 & 39.58 \\
\hline
\end{tabular}

Data source: The 2013 Annual Report of China Minsheng Banking Corporation

The second aspect is the provisions for calculating the interest according to the law of commercial banks in China. As for fixed deposits, the interest rate is fixed, which is not affected by the adjusting of interest rate. However, the interest rate of loans is adjusted by commercial banks every year according to the benchmark interest rate issued by The People's Bank of China.

\subsection{Basis Risk}

The basis risk of China's commercial banks is caused by the adjusting difference between the interest rates of assets and liabilities.

As Table 3 shows, the benchmark interest rate of deposits would not always be adjusted simultaneously when The People's Bank of China adjusted the benchmark interest rate of loans. Even under the circumstances that both interest rates were adjusted at the same time, the adjusting ranges of both interest rates were not always the same. Take the latest adjusting benchmark interest rate which occurred on July $6^{\text {th }}$ of 2012 for example. The one-year-term benchmark interest rate of deposits was decreased by 0.25 percent. Meanwhile, the one-year-term benchmark interest rate of loans was decreased by 0.31 percent. As a result, the interest rate gap between deposits and loans changed from $3.06 \%$ to $3.00 \%$. 
Table 3. The one-year-term interest rate gap between loans and deposits in China's commercial banks

\begin{tabular}{cccccccc}
\hline $\begin{array}{c}\text { Adjusting } \\
\text { Date }\end{array}$ & $\begin{array}{c}\text { One-year-term } \\
\text { interest rate of } \\
\text { deposits(\%) }\end{array}$ & $\begin{array}{c}\text { One-year-term } \\
\text { interest rate of } \\
\text { loans(\%) }\end{array}$ & $\begin{array}{c}\text { Gap } \\
(\%)\end{array}$ & $\begin{array}{c}\text { Adjusting } \\
\text { Date }\end{array}$ & $\begin{array}{c}\text { One-year-term } \\
\text { interest rate of } \\
\text { deposits(\%) }\end{array}$ & $\begin{array}{c}\text { One-year-term } \\
\text { interest rate of } \\
\text { loans(\%) }\end{array}$ & $\begin{array}{c}\text { Gap } \\
(\%)\end{array}$ \\
\hline 1996.05 .01 & 9.18 & 10.98 & 1.80 & 2007.08 .22 & 3.60 & 7.02 & 3.42 \\
\hline 1996.8 .23 & 7.47 & 10.08 & 2.61 & 2007.09 .15 & 3.87 & 7.29 & 3.42 \\
\hline 1997.10 .23 & 5.67 & 8.64 & 2.97 & 2007.12 .21 & 4.14 & 7.47 & 3.33 \\
\hline 1998.03 .25 & 5.22 & 7.92 & 2.70 & 2008.09 .16 & 4.14 & 7.2 & 3.06 \\
\hline 1998.07 .01 & 4.77 & 6.93 & 2.16 & 2008.10 .09 & 3.87 & 6.93 & 3.06 \\
\hline 1998.12 .07 & 3.78 & 6.39 & 2.61 & 2008.10 .30 & 3.6 & 6.66 & 3.06 \\
\hline 1999.06 .10 & 2.25 & 5.85 & 3.60 & 2008.11 .27 & 2.52 & 5.58 & 3.06 \\
\hline 2002.02 .21 & 1.98 & 5.31 & 3.33 & 2008.12 .23 & 2.25 & 5.31 & 3.06 \\
\hline 2004.10 .29 & 2.25 & 5.58 & 3.33 & 2010.10 .19 & 2.5 & 5.56 & 3.06 \\
\hline 2005.10 .29 & 2.25 & 5.58 & 3.33 & 2010.12 .26 & 2.75 & 5.81 & 3.06 \\
\hline 2006.04 .28 & 2.25 & 5.85 & 3.60 & 2011.02 .09 & 3 & 6.06 & 3.06 \\
\hline 2006.08 .19 & 2.52 & 6.12 & 3.60 & 2011.04 .06 & 3.25 & 6.31 & 3.06 \\
\hline 2007.03 .18 & 2.79 & 6.39 & 3.60 & 2011.07 .07 & 3.5 & 6.56 & 3.06 \\
\hline 2007.05 .19 & 3.06 & 6.57 & 3.51 & 2012.06 .08 & 3.25 & 6.31 & 3.06 \\
\hline 2007.07 .21 & 3.33 & 6.84 & 3.51 & 2012.07 .06 & 3.00 & 6.00 & 3.00 \\
\hline
\end{tabular}

Data source: The People's Bank of China (www.pbc.gov.cn)

\subsection{Optional Risk}

Optional risk refers to the bad influence caused by the underlying options in the assets, liabilities and off balance sheet businesses of commercial banks. According to the interest rate policy of China, the depositors have the right to withdraw the fixed deposits in advance. When the interest rate of deposits increases, the depositors will withdraw the deposits to deposit again in order to enjoy the higher interest rate. On the other hand, the financing enterprises will pay back the long-term loans and finance again when the interest rate of loans decreases.

\subsection{Yield Curve Risk}

Yield curve risk is the term structure risk. Because of the imperfect development of China's bond market, the benchmark yield curve of RMB bond is still far from perfect. Without the standard RMB bond benchmark for reference, China's commercial banks have to formulate the yield curves subjectively and individually to supervise or manage the market risk. Due to the small interest rate gap between the short-term and long-term state bond, the yield of liquidity would not compensate the risk factors in long-term bonds.

\section{The Empirical Measurement of Interest Rate Risk of China's Commercial Banks}

\subsection{The Measurement of Interest Rate Risk Based on the Interest Rate Sensitive Gap Approach}

The Interest Rate Sensitive Gap Approach aims to calculate the gap between interest rate sensitive assets and interest rate sensitive liabilities during a certain period. The theoretical base is that the positive interest rate sensitive gap will be good for commercial banks when the interest rate increases, and the negative interest rate sensitive gap will be good for commercial banks when the interest rate decreases.

This paper selected BOC (Bank of China) and CMB (China Merchants Bank) as research targets to calculate the interest rate sensitive gap in order to reveal the interest rate risk of China's commercial banks. BOC is a good example of state-owned commercial banks in China, and CMB can be viewed as a typical bank among those joint-equity commercial banks in China. The result of calculation based on the data from these two banks is shown as Table 4. 
Table 4. The interest rate sensitive gap of BOC and CMB between 2010 and 2012

Unit: Million Yuan

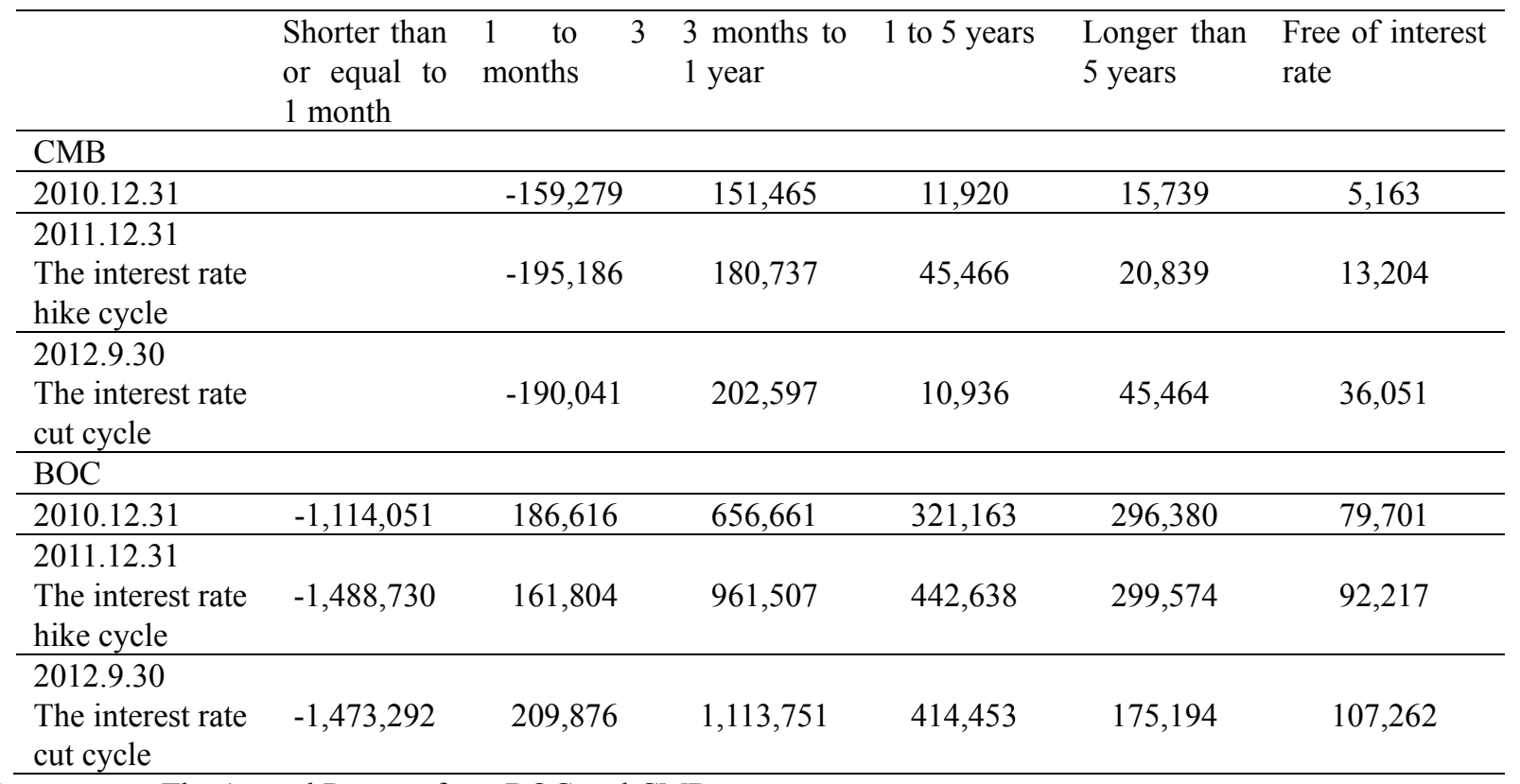

Data source: The Annual Reports from BOC and CMB

As Table 4 shows, there was a negative interest rate sensitive gap in BOC by the end of 2010 year. The gap was about -2,707.74(100 million Yuan) when the term was shorter than 1 year. The corresponding gap were respectively $-3,654.19$ (100 million Yuan) and -1,496.65(100 million Yuan) by the end of 2011 year and 2012 year. As for CMB, there were negative interest rate sensitive gaps by the end of 2010 year and 2011 year when the term was shorter than 1 year, but a positive interest rate sensitive gap by the date of September $30^{\text {th }}$ of 2012 .

According to Interest Rate Sensitive Gap Approach, the negative interest rate sensitive gap, which means the interest rate sensitive assets are smaller than the interest rate sensitive liabilities, will lead to decrease of the interest income of commercial banks when the interest rate increases. Specifically speaking, BOC and CMB, which kept negative interest rate sensitive gaps between 2010 and 2011, encountered huge interest rate risk during this certain period when the interest rate increased. In 2012 year, the interest rate of China rushed into the decreasing cycle. However, $\mathrm{CMB}$ possessed the positive interest rate sensitive gap which was also bad for the interest rate risk management.

4.2 The Measurement of Interest Rate Risk Based on the Duration Model

The formula of Duration Model is as following, $D=\frac{\sum_{t=1}^{n} \frac{t C_{t}}{(1+r)^{t}}}{P}$. D is the duration of the financial instrument. P is the present value of the financial instrument, and t means the occurring time of each cash flow. $C_{t}$ is the cash flow on the date of $\mathrm{t}$, and $\mathrm{r}$ means the interest rate of the market.

As for single asset, the duration can be calculated by imputing the data into the formula directly. When the assets possessed by commercial banks are more than one type, the Duration Model is still a useful method to reflect the risk exposure of the certain portfolio. The duration of portfolio is the weighted calculation based on the duration of each asset, and the weight is the proportion of each asset in the total assets. If $D_{i}$ stands for the duration of the i asset, $D_{p}$ stands for the duration of portfolio, $\mathrm{P}$ means the present value of total assets, $P_{i}$ is the present value of the i 
asset, then $D_{p}=\frac{\sum_{i=1}^{n} D_{i} P_{i}}{P}=\sum_{i=1}^{n} D_{i} W_{i}$, and $W_{i}$ is the weight.

This paper carries out the empirical measurement based on the data of the treasure bonds possessed by CMBC (China Minsheng Banking Corporation) by the end of 2013.

The data used for empirical measurement is shown in Ttable 5. After processing the data in Table 5, the results of the duration of portfolio are shown as Table 6 .

Table 5. The treasure bonds possessed by CMBC by the end of 2013

\begin{tabular}{lcccc}
\hline \multicolumn{1}{c}{ Treasure bond } & $\begin{array}{c}\text { Par value (Million } \\
\text { Yuan) }\end{array}$ & $\begin{array}{c}\text { Annual interest } \\
\text { rate (\%) }\end{array}$ & $\begin{array}{c}\text { The remaining } \\
\text { period (Year) }\end{array}$ & Duration date \\
\hline $\begin{array}{l}\text { Book-entry } \\
\text { T-bond of 2005 }\end{array}$ & 1,227 & 4.69 & 8.5 & $2022-11-6$ \\
\hline $\begin{array}{l}\text { Book-entry } \\
\text { T-bond of 2006 }\end{array}$ & 1,632 & 2.93 & 0.92 & $2015-2-6$ \\
\hline $\begin{array}{l}\text { Book-entry } \\
\text { T-bond of 2007 }\end{array}$ & 9,888 & 2.66 & 5.33 & $2019-4-9$ \\
\hline $\begin{array}{l}\text { Book-entry } \\
\text { T-bond of 2008 }\end{array}$ & 4,662 & 2.51 & 5.25 & $2019-2-27$ \\
\hline $\begin{array}{l}\text { Book-entry } \\
\text { T-bond of 2009 }\end{array}$ & 1,605 & 3.90 & 5.67 & $2019-8-23$ \\
\hline $\begin{array}{l}\text { Book-entry } \\
\text { T-bond of 2012 }\end{array}$ & 5,930 & 4.16 & 15.17 & $2029-2-28$ \\
\hline \multicolumn{1}{c}{ Total } & 24,943 & & & \\
\hline
\end{tabular}

Table 6. The calculation process of duration of treasure bonds possessed by CMBC

\begin{tabular}{lcccccc}
\hline Treasure bond & $\begin{array}{l}\text { The bid price } \\
\text { data of Apr. } \\
27^{\text {th }} \text { in } 2014 \\
\text { (Note 1) }\end{array}$ & $\begin{array}{l}\text { The } \\
\text { possessed by bank } \\
(10 \text { thousand Yuan) } \\
\text { (Note 2) }\end{array}$ & & $\begin{array}{l}\text { The yield to } \\
\text { maturity } \\
\text { (Note 3) }\end{array}$ & $\begin{array}{l}\text { Duration } \\
\text { (Note 4) }\end{array}$ & $\begin{array}{l}W_{i} \\
* \text { Duration }\end{array}$ \\
\hline $\begin{array}{l}\text { Book-entry } \\
\text { T-bond of 2005 }\end{array}$ & 95.32 & $1,169.58$ & 0.0487 & $5.28 \%$ & 6.86 & 0.3341 \\
\hline $\begin{array}{l}\text { Book-entry } \\
\text { T-bond of 2006 }\end{array}$ & 100.386 & $1,638.29$ & 0.0683 & $2.54 \%$ & 0.87 & 0.0594 \\
\hline $\begin{array}{l}\text { Book-entry } \\
\text { T-bond of 2007 }\end{array}$ & 96.48 & $9,539.94$ & 0.3976 & $3.36 \%$ & 4.76 & 1.8926 \\
\hline $\begin{array}{l}\text { Book-entry } \\
\text { T-bond of 2008 }\end{array}$ & 99.57 & $4,641.95$ & 0.1935 & $2.62 \%$ & 3.86 & 0.7469 \\
\hline $\begin{array}{l}\text { Book-entry } \\
\text { T-bond of 2009 }\end{array}$ & 98.89 & $1,587.18$ & 0.0661 & $4.12 \%$ & 4.64 & 0.3067 \\
\hline $\begin{array}{l}\text { Book-entry } \\
\text { T-bond of 2012 }\end{array}$ & 91.35 & $5,417.06$ & 0.2258 & $4.78 \%$ & 10.98 & 2.4792 \\
\hline \multicolumn{7}{c}{ Total } \\
\hline
\end{tabular}

The above table of duration data shows that the portfolio duration of treasure bonds possessed by CMBC is 5.8189 . That is to say that if the yield increases by 100 base points the value of the bond portfolio will decrease by 5.8189 percent, which reflects the accounting loss of interest rate risk exposure. From the website of China Government Securities Depository Trust \& Clearing Corporation, the average yield to maturity is $2.6793 \%$ on the Apr. 27th of 2012, and the average yield to maturity is $3.0620 \%$ on the Apr. 27th of 2014. Thus, the average yield to maturity increased by 38.27 base points during the period between the Apr. 27th of 2012 and the Apr. 27th of 2014. According to the portfolio duration of treasure bonds possessed by CMBC, the accounting loss during this certain period is $23,994 * 0.3827 * 5.8189 \%=534.32(10$ thousand Yuan). 


\section{The Countermeasures and Suggestions to Enhance the Interest Rate Risk Management of China's Commercial Banks}

\subsection{The Organizational Reconstruction Based on the Interest Rate Risk Management}

China's commercial banks should establish ALMC (Assets \& Liabilities Management Commission), which is a special institution to be responsible for interest rate risk management. The members of ALMC should be selected from two parts. One part is the development planning department which is good at analyzing macroeconomic and industrial policies. The other part is the assets \& liabilities management department which is familiar with the allocation of assets and liabilities of commercial banks.

\subsection{To Establish Scientific and Effective Pricing Institution for Financial Products}

China's commercial banks should establish a pricing management system for financial products with an effective graded authorization. The headquarters of commercial banks should establish the inner bid system for financial products in order to supply the clear benchmark of costs. Meanwhile, the scientific graded authorization system should be established to provide the branches pricing-floating rights according to different business styles, quotas, terms and risk levels.

\subsection{To Improve the Risk Management Ability Based on the Reasonable Allocation of Financial Derivatives}

The trade of financial derivatives is always active, and the transactional style is always flexible. To apply financial derivatives into the management of interest rate risk can achieve the rapid improvement on the interest rate position of commercial banks under a low cost, which will not affect the structure of assets and liabilities.

\section{References}

Chen, Bo, \& Yao, Jianli. (2005). The Application of Duration Analysis in the Risk Management of Commercial Banks. Finance \&Insurance, (6), 97-99.

Deng, Ran. (2011). The Research on Interest Rate Risk of China's Commercial Banks. Financial Theory and Practice, (2), 72-73.

Huang, Jinlao. (2001). The Interest Rate Liberalization and Risk Management of Commercial Banks. Economic Research, (1).

Li, Yan. (2000). The Interest Rate Risk Management of China’s Commercial Banks. Finance \&Trade Economics, (9), 33-37.

Wang, Heying. (2008). The Interest Rate Risk Management of Commercial Banks under the background of RMB Exchange Rate Appreciation. Financial Observation, (12), 37-39.

Wang, Qiang. (2010). The Correlation between Interest Rate Liberalization and Monetary Supply. Economic Theory and Economic Management, (1), 46-48.

Yao, Yuan. (2012). The Countermeasures of Interest Rate Risk of Commercial Banks. Financial Forum, (11), $45-51$.

Notes

Note 1. The bid price data of market are gathered from the website, www.chinabond.com.cn

Note 2. The data in this column is calculated by the par value in table 5 times the bid price and divides 100

Note 3. Data source: calculated by the IRR(a1:a12) function in Excel

Note 4. The duration data is calculated by imputing the relative data into the formula of duration 